\title{
Effects of anionic supplement source in prepartum negative dietary cation-anion difference diets on serum calcium, feed intake, and lactational performance of multiparous dairy cows
}

\author{
Luciano S. Caixeta, ${ }^{1} \odot$ Wanda J. Weber, ${ }^{2}$ ๑ Danielle M. Johnson, ${ }^{2}$ Jill Faser, ${ }^{3}$ Barry M. Visser, ${ }^{4}$ \\ and Brian A. Crooker ${ }^{2 *}$ (1) \\ ${ }^{1}$ Department of Veterinary Population Medicine, University of Minnesota, Saint Paul 55108 \\ ${ }^{2}$ Department of Animal Science, University of Minnesota, Saint Paul 55108 \\ ${ }^{3}$ Origination $\mathrm{O}_{2} \mathrm{D}$ Inc., Maplewood, MN 55119 \\ ${ }^{4}$ Vita Plus Corporation, Madison, WI 53725
}

\section{ABSTRACT}

Incidence of subclinical hypocalcemia in early postpartum dairy cows continues to be an animal welfare concern and an economic burden for producers. Feeding prepartum negative dietary cation-anion difference (DCAD) diets produces metabolic acidosis, which supports mobilization of bone calcium and reduces the incidence of hypocalcemia. Achieving a sufficient degree of metabolic acidosis without reducing dry matter intake (DMI) can be difficult. This study compared the ability of MegAnion (MA; Origination O2D Inc., Maplewood, $\mathrm{MN}$ ), a new DCAD supplement designed to be more palatable than typical anionic salt sources, and another palatable commercial DCAD product, SoyChlor (SC; Landus Cooperative, Ralston, IA), to reduce urine $\mathrm{pH}$ (a surrogate for metabolic acidosis) without reducing prepartum DMI. A secondary objective was to assess the effect of these anionic supplements on postpartum serum calcium concentrations and DMI. Prepartum multiparous Holstein (HO) and crossbred (XX) cows were blocked by breed and expected calving date and randomly assigned within breed to total mixed rations (TMR) with MA or SC and DCAD values of -215 $\mathrm{mEq} / \mathrm{kg}$ of DM. Cows $(\mathrm{n}=56 ; 15 \mathrm{MA}-\mathrm{HO}, 12 \mathrm{SC}-$ HO, 15 MA-XX, 14 SC-XX) consumed the treatment TMR for at least $19 \mathrm{~d}$ and completed the $28 \mathrm{~d}$ in milk (DIM) phase of the study. Urine and blood samples were collected weekly and at 1,2, and 3 DIM. Data were analyzed as a randomized block design by repeated measures with week or DIM as the repeated effect. Prepartum urine $\mathrm{pH}$ decreased from $8.15 \pm 0.27$ before treatment to $6.12 \pm 0.14$ during treatment, was not affected by anionic supplement, and increased im-

Received May 20, 2019.

Accepted December 20, 2019.

*Corresponding author: crook001@umn.edu mediately after calving when all cows consumed the same early-lactation TMR. Prepartum serum calcium concentrations were not affected (2.34 vs. $2.33 \pm 0.02$ $\mathrm{mmol} / \mathrm{L})$ by treatment, whereas nonesterified fatty acids were lower ( 86 vs. $120 \pm 10 \mathrm{mmol} / \mathrm{L}$ ) and insulin was greater (215 vs. $174 \pm 10 \mathrm{pmol} / \mathrm{L}$ ) in cows fed MA than in cows fed SC. These differences are supported by the numerically greater prepartum DMI $(1.2 \mathrm{~kg} / \mathrm{d})$ and energy balance $(1.8 \mathrm{Mcal} / \mathrm{d})$ of cows fed MA. However, pre- and postpartum DMI and other production variables, including body weight, body condition score, milk yield, and energy balance, were not affected by treatment. This lack of difference indicates that MA provides another effective source of anionic salts for diets designed to reduce urine $\mathrm{pH}$ and induce metabolic acidosis in prepartum dairy cows.

Key words: subclinical hypocalcemia, anionic salt, dietary cation-anion difference diet, urine $\mathrm{pH}$

\section{INTRODUCTION}

Hypocalcemia has been reported as a problem in early-lactation dairy cows for more than 2 centuries (Murray et al., 2008). Clinical hypocalcemia or milk fever is typically defined as blood Ca concentration $<1.4 \mathrm{mmol} / \mathrm{L}$ with the presence of clinical signs (i.e., recumbency, lethargy, hypothermia, and rumen atony), and subclinical hypocalcemia $(\mathbf{S C H})$ is characterized as blood Ca concentration $\leq 2.15 \mathrm{mmol} / \mathrm{L}$ without visible clinical signs (Reinhardt et al., 2011; Martinez et al., 2012). More effective nutritional management during the dry period and early lactation and a greater understanding of transition cow physiology have helped decrease the incidence of milk fever to $1 \%$ or less (Reinhardt et al., 2011; Oetzel and Miller, 2012). Conversely, the incidence of $\mathrm{SCH}$ remains high during the first 3 DIM, with estimates ranging from 25 to $73 \%$ and increasing with parity (Reinhardt et al., 2011; Caixeta et 
al., 2015). It is important to highlight that even in the absence of clinical signs, low blood Ca can predispose a cow to impaired immune function, metritis, displaced abomasum, impaired reproductive performance, and increased risk of culling (Chapinal et al., 2011; Martinez et al., 2012; Caixeta et al., 2017).

Feeding prepartum cows a negative-DCAD diet induces a state of compensated metabolic acidosis, which enhances the capacity to mobilize Ca from bones while maintaining parathyroid hormone activity (Goff and Horst, 2003). This increased availability of Ca explains the beneficial effects of feeding negative-DCAD diets to the periparturient cow (Goff and Horst, 2003; MartínTereso and Verstegen, 2011; Goff, 2018). NegativeDCAD diets can be formulated through the inclusion of anionic salts. Although the optimum DCAD value for prepartum diets has not been established (Leno et al., 2017; Santos et al., 2019), dairy producers have been using negative-DCAD diets for more than $30 \mathrm{yr}$ to reduce the incidence of milk fever and SCH (Iwaniuk and Erdman, 2015). Nonetheless, the incidence of postpartum SCH continues to be a concern for the dairy industry, and considerable interest is directed toward improving our understanding of factors that affect the effectiveness of anionic supplements used to produce negative-DCAD diets (Leno et al., 2017; Lopera et al., 2018; Santos et al., 2019).

MegAnion (MA; Origination O2D Inc., Maplewood, $\mathrm{MN}$ ) is designed to be a palatable anionic supplement that can be used to formulate negative-DCAD diets for prepartum cows. This extruded organic complex is manufactured to contain a large amount $(>22 \%$ of DM) of $\mathrm{Cl}$ (Origination O2D Inc., 2019), which reduces the amount needed to achieve a desired DCAD value. Our preliminary use of the product indicates that the extrusion process produces a stable organic complex that is easy to handle and is readily accepted by dairy cattle (B. A. Crooker and J. Faser, unpublished data). The greater chloride content contributes to the need to use less MA than other salt mixtures to achieve a desired DCAD value. MegAnion provides an option to formulate negative-DCAD rations with a minimal effect on dietary energy and nutrient content (low inclusion rate).

The hypothesis of this study was that prepartum diets formulated with MA would provide the same physiological benefits to the cow as another commercial chloride-based source of anionic salts, SoyChlor (SC; Landus Cooperative, Ralston, IA), if the diets were formulated to have similar DCAD values. The primary objectives of the study were to determine the effects of DCAD supplement source on prepartum urine $\mathrm{pH}$, serum Ca concentration, and DMI when dry cows were fed negative-DCAD diets formulated with supplements based on MA or SC. The secondary objectives were to determine the effects of these prepartum DCAD sources on postpartum serum Ca concentration and DMI.

\section{MATERIALS AND METHODS}

\section{Animals and Experimental Design}

The experiment was conducted at the University of Minnesota Dairy Cattle Teaching and Research Facility on the University of Minnesota St. Paul campus from September 2017 through March 2018. All procedures for animal handling and care were approved by the University of Minnesota Institutional Animal Care and Use Committee. Holstein (HO; $\mathrm{n}=36)$ and crossbred $(\mathbf{X X} ; \mathrm{n}=30)$ cows entering their second or greater lactation were enrolled, housed in individual tiestalls, and fed nonlimiting amounts of TMR. All cows had been housed at the dairy for at least 1 complete lactation before enrollment and were well accustomed to the facility, procedures, and handling conditions. Crossbreeding at this dairy since the early 2000s has produced Montbéliarde $\times \mathrm{HO}$, Jersey $\times \mathrm{HO}$, and most recently a rotational cross of $\mathrm{HO}$, Montbéliarde, and Viking (Swedish) Red. The distribution of these 30 heterogeneous XX cows in a reverse sire breed sequence grouping was $4 \mathrm{HSMH}, 5 \mathrm{MHSMH}, 12 \mathrm{MSHMJH,} 1$ SHMHJH, 7 SHMJH, and 1 SMHSMH, where each letter is the corresponding first letter of one of the breeds ( $\mathrm{S}$ for Swedish Red) that were used in this effort. Previous work (Leno et al., 2017) and results from our dairy with multiparous HO and XX cows (Weich et al., 2013) were used to estimate variances for prepartum $\mathrm{pH}(0.49$ units), serum Ca $(0.11 \mathrm{mmol} / \mathrm{L})$, and DMI $(2.9 \mathrm{~kg} / \mathrm{d})$ and for postpartum serum Ca $(0.11 \mathrm{mmol} / \mathrm{L})$ and DMI $(4.0 \mathrm{~kg} / \mathrm{d})$. A power analysis indicated that 30 cows per treatment should provide sufficient power $(>80 \%)$ to detect $(P<0.05)$ prepartum differences of $0.36 \mathrm{pH}$ units, $0.08 \mathrm{mmol}$ of $\mathrm{Ca} / \mathrm{L}$, and $2.1 \mathrm{~kg}$ of $\mathrm{DMI} / \mathrm{d}$. Comparable differences with 16 cows per breed $\times$ treatment combination were $0.50 \mathrm{pH}$ units, $0.11 \mathrm{mmol}$ of $\mathrm{Ca} / \mathrm{L}$, and $2.9 \mathrm{~kg}$ of $\mathrm{DMI} / \mathrm{d}$. The power analysis indicated that postpartum differences of 0.08 and $0.11 \mathrm{mmol}$ of $\mathrm{Ca} / \mathrm{L}$ and 2.9 and $4.0 \mathrm{~kg}$ of $\mathrm{DMI} / \mathrm{d}$ could be detected with 30 cows per treatment and with 16 cows per breed $\times$ treatment combination, respectively.

Cows were blocked by breed (HO or XX) and expected calving date and randomly assigned within breed to consume a prepartum TMR that contained a DCAD premix formulated with $\mathrm{MA}$ or $\mathrm{SC}$ as the primary source of anionic salts (Table 1 ). This $2 \times 2$ factorial arrangement generated 4 treatments: MA fed 
to HO (MA-HO) or XX (MA-XX) cows and SC fed to $\mathrm{HO}(\mathrm{SC}-\mathrm{HO})$ or XX (SC-XX) cows. The premixes had DCAD values of $-1,147$ and $-1,172 \mathrm{mEq} / \mathrm{kg}$ of $\mathrm{DM}$, respectively, and were mixed into the same basal prepartum TMR formulated to have a DCAD of -156 $\mathrm{mEq} / \mathrm{kg}$ of DM. These prepartum treatment TMR (Table 2) were fed beginning $28 \pm 3 \mathrm{~d}$ before expected calving through actual calving. Cows had to consume the treatment for at least $19 \mathrm{~d}$ to remain in the study. After calving, all cows received the same postpartum diet (Table 2) through 28 DIM. Cows were fed once daily between 0930 and $1100 \mathrm{~h}$ and milked twice daily between 0400 and $0800 \mathrm{~h}$ and between 1600 and 2000 h. Milk yield and amounts of feed offered and refused were determined daily.

\section{Measurements, Sample Collection, and Analysis}

Urine and blood samples were collected on Tuesdays between 1000 and $1200 \mathrm{~h}$ on the day before treatment initiation and weekly thereafter through 4 wk postpartum. Urine and blood samples were also collected at 1 ,

Table 1. Ingredient composition of the dry-period DCAD premixes

\begin{tabular}{lcc}
\hline & \multicolumn{2}{c}{ DCAD premix } \\
\cline { 2 - 3 } Ingredient, \% of DM & MegAnion & SoyChlor \\
\hline Soybean meal, 47\% protein & 21.61 & 43.28 \\
Soy hulls & 28.73 & 9.24 \\
Canola meal & 21.61 & - \\
Blood meal & 2.46 & 2.52 \\
MegAnion anionic supplement ${ }^{1}$ & 14.64 & - \\
Soychlor anionic supplement ${ }^{2}$ & - & 34.45 \\
Urea, 46\% $_{\text {Dicalcium phosphate, } 21 \%}$ & 0.55 & 1.40 \\
Calcium carbonate & 3.15 & - \\
Magnesium oxide, 54\% & 1.09 & - \\
Magnesium sulfate with 7H $_{2} \mathrm{O}$ & - & 0.98 \\
Ammonium chloride & - & 0.70 \\
Bio-Sel Dry Cow 1000 with Rumensin & \\
ReaShure Choline $^{4}$ & 2.46 & 2.52 \\
Animal fat & 1.92 & 1.96 \\
Vitamin E $^{5}$ & 0.82 & 0.84 \\
Yeast DV XPC $^{6}$ & 0.55 & 0.56 \\
\hline 1Orination & 0.41 & 0.42 \\
\hline
\end{tabular}

${ }^{1}$ Origination O2D Inc., Maplewood, MN. Contains (\% of DM) $81.5 \%$ CP, $3.8 \%$ ADF, $7.5 \%$ NDF, $0.52 \%$ ether extract, $0.26 \% \mathrm{Ca}, 0.49 \% \mathrm{P}$, $2.5 \% \mathrm{Mg}, 1.60 \% \mathrm{~K}, 0.07 \% \mathrm{Na}, 23.7 \% \mathrm{Cl}$, and $3.1 \% \mathrm{~S} . \mathrm{DCAD}=(\mathrm{Na}$ $+\mathrm{K})-(\mathrm{Cl}+\mathrm{S})=-8,270 \mathrm{mEq} / \mathrm{kg}$ of DM according to Goff $(2018)$. ${ }^{2}$ Landus Cooperative, Ralston, IA. Contains (\% of DM) $20.1 \%$ CP, $2.4 \%$ ADF, 26\% NDF, 27.9\% NFC, $5.1 \%$ ether extract, $4.5 \% \mathrm{Ca}$, $0.30 \% \mathrm{P}, 2.8 \% \mathrm{Mg}, 0.48 \% \mathrm{~K}, 0.04 \% \mathrm{Na}, 10.3 \% \mathrm{Cl}$, and $0.35 \% \mathrm{~S}$. DCAD $=(\mathrm{Na}+\mathrm{K})-(\mathrm{Cl}+\mathrm{S})=-2,980 \mathrm{mEq} / \mathrm{kg}$ of DM according to Goff (2018).

${ }^{3}$ Dry cow mineral supplement (Vita Plus Corporation, Madison, WI) with $4.03 \mathrm{~g} / \mathrm{kg}$ Rumensin (Elanco, Greenfield, IN).

${ }^{4}$ Balchem, New Hampton, NY.

${ }^{5} 44,000 \mathrm{IU} / \mathrm{kg}$.

${ }^{6}$ Diamond V, Cedar Rapids, IA.
2 , and $3 \mathrm{~d}$ postpartum. Urine and blood were collected within $24 \mathrm{~h}$ after calving for the 1-d postpartum sample. Manual stimulation was used when necessary to collect clean, mid-stream urine samples. Urine $\mathrm{pH}$ was determined within 30 min of collection using a CMS

Table 2. Ingredient and nutrient content of the TMR

\begin{tabular}{|c|c|c|c|}
\hline \multirow[b]{2}{*}{ Component } & \multicolumn{2}{|c|}{ Dry-period TMR } & \multirow{2}{*}{$\begin{array}{c}\text { Lactation } \\
\text { TMR }\end{array}$} \\
\hline & MegAnion & SoyChlor & \\
\hline \multicolumn{4}{|l|}{ Ingredient, $\%$ of DM } \\
\hline Corn gluten feed & 7.80 & 7.81 & 5.45 \\
\hline Corn silage & 35.88 & 35.92 & 40.36 \\
\hline Grass hay & 34.95 & 35.38 & - \\
\hline MegAnion premix ${ }^{1}$ & 21.37 & - & - \\
\hline SoyChlor premix ${ }^{2}$ & - & 20.89 & - \\
\hline Alfalfa hay & - & - & 14.36 \\
\hline Milk cow protein $\operatorname{mix}^{3}$ & - & - & 20.00 \\
\hline QLF commercial dairy $\operatorname{mix}^{4}$ & - & - & 4.55 \\
\hline Cottonseed, fuzzy & - & - & 5.45 \\
\hline Ground shell corn & - & - & 9.09 \\
\hline Energy Booster $100^{5}$ & - & - & 0.73 \\
\hline \multicolumn{4}{|l|}{ Nutrient content,${ }^{6}$ DM basis } \\
\hline DM, \% & 55.1 & 55.9 & 51.7 \\
\hline $\mathrm{CP}, \%$ & 14.6 & 14.6 & 15.5 \\
\hline $\mathrm{ADF}, \%$ & 27.3 & 29.7 & 19.2 \\
\hline NDF, $\%$ & 46.3 & 45.6 & 29.8 \\
\hline TDN, $\%$ & 67.3 & 67.3 & 72.0 \\
\hline $\mathrm{NE}_{\mathrm{L}}, \mathrm{Mcal} / \mathrm{kg}$ & 1.57 & 1.58 & 1.69 \\
\hline $\mathrm{NE}_{\mathrm{M}}, \mathrm{Mcal} / \mathrm{kg}$ & 1.53 & 1.53 & 1.73 \\
\hline $\mathrm{Ca}, \%$ & 0.50 & 0.67 & 0.65 \\
\hline$P, \%$ & 0.39 & 0.41 & 0.39 \\
\hline $\mathrm{Mg}, \%$ & 0.40 & 0.44 & 0.34 \\
\hline $\mathrm{K}, \%$ & 0.97 & 0.98 & 1.22 \\
\hline $\mathrm{Na}, \%$ & 0.09 & 0.10 & 0.40 \\
\hline $\mathrm{Fe}, \mathrm{mg} / \mathrm{kg}$ & 340 & 279 & 276 \\
\hline $\mathrm{Zn}, \mathrm{mg} / \mathrm{kg}$ & 108 & 88.0 & 74.3 \\
\hline $\mathrm{Cu}, \mathrm{mg} / \mathrm{kg}$ & 15.5 & 17.5 & 14.5 \\
\hline $\mathrm{Mn}, \mathrm{mg} / \mathrm{kg}$ & 84.3 & 93.0 & 64.8 \\
\hline Мо, $\%$ & 1.3 & 1.5 & 1.8 \\
\hline $\mathrm{S}, \%$ & 0.30 & 0.26 & 0.29 \\
\hline $\mathrm{Cl}$ ion, \% & 1.08 & 1.28 & 0.53 \\
\hline $\mathrm{DCAD},{ }^{7} \mathrm{mEq} / \mathrm{kg}$ & -200 & -228 & 153 \\
\hline
\end{tabular}

${ }^{1}$ Origination O2D Inc., Maplewood, MN. See Table 1 for composition.

${ }^{2}$ Landus Cooperative, Ralston, IA. See Table 1 for composition.

${ }^{3}$ Extrafine rolled corn, $29.72 \%$; soybean meal $47 \%$ protein, $17.50 \%$; canola meal, 12.50\%; Amino Plus (AG Processing Inc., Omaha, NE), $8.75 \%$; blood meal, $6.25 \%$; calcium carbonate, $5.50 \%$; sodium bicarbonate, $5.00 \%$; distillers grain, $5.00 \%$; WR Elite Dairy Micro (Vita Plus Corporation, Madison, WI), 2.50\%; potassium carbonate, $2.00 \%$; UltraMet (Vita Plus Corporation), 2.00\%; sodium chloride, $2.00 \%$; urea $46 \%$ N, 1.25\%; Rumensin 90 (Elanco Animal Health, Greenfield, IN), $0.03 \%$.

${ }^{4}$ Quality Liquid Feeds, Dodgeville, WI. Molasses-based liquid supplement of soluble sugars and protein developed from cane molasses, condensed whey, urea, and sulfuric acid. The liquid supplement DM contained total sugars as invert, $58.6 \%$; CP, $11.8 \%$; NPN, $38 \%$; fat, $0.5 \%$; Ca, $1.16 \%$; P, 0.42\%; K, 4.82\%; Mg, 0.47\%; S, 0.95\%; Na, $0.47 \%$; and $\mathrm{Cl}, 2.86 \%$.

${ }^{5}$ Milk Specialties Global, Eden Prairie, MN. Hydrolyzed animal and vegetable fat.

${ }^{6}$ Means from analyses of composites $(\mathrm{n}=4)$ generated from 8 weekly samples for each TMR.

${ }^{7} \mathrm{DCAD}=(\mathrm{Na}+\mathrm{K})-(\mathrm{Cl}+\mathrm{S})$ according to Goff $(2018)$. 
Labcraft pH 101 meter with a 024-050 probe (Curtin Matheson Scientific, Houston, TX) that was calibrated before each use with standard buffer solutions ( $\mathrm{pH} 4.0$, 7.0, and 10.0). Blood samples were collected from coccygeal vessels using vacuum serum tubes (Vacutainer; Becton Dickinson, Franklin Lakes, NJ) and allowed to clot at room temperature for 30 min before serum was isolated by centrifugation at $1,200 \times g$ for $20 \mathrm{~min}$ at $4^{\circ} \mathrm{C}$. Serum was aspirated and stored at $-20^{\circ} \mathrm{C}$ until analyzed.

Milk samples were collected from consecutive p.m. and a.m. milkings once weekly. A proportional sampler was attached to the milking unit to collect a representative sample of each cow's entire milking. A 30- to 50-mL aliquot of each sample was preserved with liquid Bronolab-W II for analysis (Stearns County DHIA Laboratory, Sauk Centre, MN) of fat, true protein, lactose, and SCC with a CombiScope FTIR 600HP (PerkinElmer, Waltham, MA). Grab samples of the TMR from individual batches were composited weekly and $\mathrm{DM}$ at $60^{\circ} \mathrm{C}$ for $48 \mathrm{~h}$ was determined. Composites $(\mathrm{n}=4 / \mathrm{TMR})$ from 8 -wk periods were analyzed (Dairy One Forage Testing Laboratory, Ithaca, NY) using wet chemistry techniques. Sample DM was determined in a forced-air oven at $60^{\circ} \mathrm{C}$ for $4 \mathrm{~h}$, with residual moisture determined by near-infrared reflectance spectroscopy (method 991.01; AOAC International, 2006) and CP concentration determined by combustion (method 990.03; AOAC International, 2006). Sample fiber concentrations were determined (Ankom Technology, 2017) using method 973.18 (AOAC International, 2006) for $\mathrm{ADF}$ and using detergent solutions with heat-stable

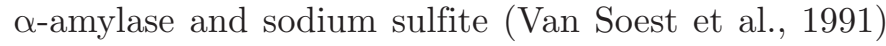
for NDF. Sample Ca, P, Mg, K, Na, Fe, Zn, Cu, Mn, $\mathrm{Mo}$, and $\mathrm{S}$ concentrations were determined using inductively coupled plasma methodology after microwave digestion (MARS 6) with $\mathrm{NHO}_{3}, \mathrm{HCl}$, and $\mathrm{H}_{2} \mathrm{O}_{2}$ (CEM Corporation, 2019). Sample Cl ion concentrations were determined by potentiometric titration with $\mathrm{AgNO}_{3}$ after digestion with $\mathrm{HNO}_{3}$ (Cantliffe et al., 1970). Throughout the study, BW and BCS were measured weekly. The same trained evaluator scored BCS at 0.25-unit intervals (NRC, 2001).

Serum nonesterified fatty acid [NEFA; NEFA-HR (2), Wako Life Sciences, Mountain View, CA] concentrations were determined by colorimetric assays with volumes modified for use in a 96-well plate. Samples were analyzed in duplicate. Intra- and interassay coefficients of variation were 6.4 and $11.3 \%$, respectively. Serum insulin concentrations were measured using a porcine insulin RIA (Millipore, Billerica, MA). The assay was validated (data not presented) for recovery and linearity of dilution with bovine serum. Samples were analyzed in duplicate. The minimal detectable concentration was $1.6 \mu \mathrm{U} / \mathrm{mL}$, and the intra- and interassay coefficients of variation were 5.8 and $5.3 \%$, respectively. Serum samples submitted to the Marshfield Veterinary Laboratory (Marshfield, WI) for the determination of total $\mathrm{Ca}, \mathrm{K}, \mathrm{Mg}$, glucose, BUN, and BHB concentrations were analyzed using a high-throughput chemistry analyzer (AU680, Beckman Coulter, Brea, CA). Intraand interassay coefficients of variation for these serum components were less than 3 and $5 \%$, respectively.

\section{Calculations and Statistical Analysis}

As-fed intake was determined daily. Weekly DMI was calculated from study initiation through 4 wk postpartum for each cow. Milk composition was calculated from milk weight adjusted values of samples collected from consecutive p.m. and a.m. milkings and multiplied by average daily yields each week to obtain daily yields of milk components for each week of lactation. Weekly $3.5 \%$ FCM yields were calculated according to Tyrrell and Reid (1965). Energy balance was calculated according to NRC (2001) as energy intake minus energy needs for maintenance (including growth for cows entering their second lactation) and pregnancy for prepartum cows and as energy intake minus energy needs for maintenance (including growth for second-lactation cows) and milk produced for postpartum cows. The potential contribution of changes in tissue energy was not included in these calculations due to the inability to accurately assign change in BW between change in tissue weight and change in gut fill during the transition from pregnancy to lactation (NRC, 2001).

Blood serum and urine data from each of 3 intervals (the 4 wk of prepartum treatment, the first $3 \mathrm{~d}$ of lactation, and the first $4 \mathrm{wk}$ of lactation) and production variables from each of 2 intervals (the 4 -wk prepartum treatment and the first $4 \mathrm{wk}$ of lactation) were analyzed separately using a randomized block design by repeated measures (PROC MIXED of SAS; SAS Institute Inc., Cary, NC) with week of lactation or DIM as the repeated effect and first-order autoregressive as the covariance structure. The Kenward-Roger procedure was used to adjust the denominator degrees of freedom. The model included all main effects (diet, breed, and week or DIM) and their interactions as fixed effects and block as a random effect. Pretreatment urine $\mathrm{pH}$ and serum component concentrations from the day before treatment initiation were used as covariates for analysis of the prepartum urine $\mathrm{pH}$ and serum component data, respectively. Results are reported as least squares means. Means were considered to differ when $P \leq 0.05$ and trends were identified when $0.05<P \leq 0.10$. 
Table 3. Descriptive characteristics of the study population

\begin{tabular}{|c|c|c|c|c|}
\hline \multirow[b]{2}{*}{ Variable } & \multicolumn{4}{|c|}{ Treatment $\times$ breed $^{1}$} \\
\hline & MA-HO & SC-HO & MA-XX & SC-XX \\
\hline \multicolumn{5}{|l|}{ Prepartum } \\
\hline \multicolumn{5}{|l|}{ Cows, ${ }^{2} \mathrm{n}$} \\
\hline Parity 2 & 8 & 6 & 7 & 5 \\
\hline Parity 3 & 5 & 8 & 7 & 4 \\
\hline Parity 4+ & 5 & 1 & 1 & 5 \\
\hline \multicolumn{5}{|c|}{ Treatment length, d } \\
\hline Mean $\pm \mathrm{SD}$ & $27.8 \pm 3.6$ & $28.2 \pm 5.7$ & $29.6 \pm 5.6$ & $28.1 \pm 5.7$ \\
\hline \multirow{2}{*}{\multicolumn{5}{|c|}{ Postpartum $^{3}$}} \\
\hline & & & & \\
\hline Cows, $\mathrm{n}$ & 15 & 12 & 15 & 14 \\
\hline \multicolumn{5}{|c|}{$\begin{array}{l}{ }^{1} \text { Treatment groups were developed from a } 2 \times 2 \text { factorial arrangement of breed [multiparous Holstein (HO) } \\
\text { or crossbred }(\mathrm{XX}) \text { cows] and treatment [dry-cow TMR based on MegAnion (MA; Origination O2D Inc., } \\
\text { Maplewood, MN) or SoyChlor (SC; Landus Cooperative, Ralston, IA)]. } \\
{ }^{2} \text { Number of cows by parity at time of on-study calving. } \\
{ }^{3} \text { Cows }(\mathrm{n}=6 \text { ) removed after calving: a second-parity MA-HO due to caesarean birth; a fourth-parity MA-HO, } \\
\text { a third-parity SC-HO, and a second-parity SC-HO due to milk fever with displaced abomasal surgery; a fifth- } \\
\text { parity MA-HO due to milk fever; and a third-parity SC-HO due to displaced abomasal surgery. }\end{array}$} \\
\hline
\end{tabular}

\section{RESULTS}

\section{Descriptive Results}

The MA supplement contained more $\mathrm{Cl}$ (23.7 vs. $10.3 \%$ of $\mathrm{DM})$ and had a more negative $\mathrm{DCAD}$ value $(-8,270$ vs $-2,980 \mathrm{mEq} / \mathrm{kg}$ of $\mathrm{DM})$ than the SC supplement, so less MA than SC (Table 1) was needed to achieve the formulated DCAD value of $-1,150 \mathrm{mEq} / \mathrm{kg}$ of DM for the premixes. Similar amounts of the premixes were used in their respective TMR (Table 2). Macronutrient analysis of the pre- and postpartum TMR was consistent $( \pm 5 \%)$ with formulated values (data not presented). Measured $\mathrm{Na}, \mathrm{Cl}$, and $\mathrm{P}$ concentrations of the prepartum treatment TMR were also within $\pm 5 \%$ of formulation. However, measured $\mathrm{S}$ concentration was $8 \%$ more and $\mathrm{K}(-19 \%), \mathrm{Mg}(-15 \%)$, and $\mathrm{Ca}(-31 \%)$ concentrations were less than formulated values for the prepartum TMR. The DCAD values $(-200$ and -228 $\mathrm{mEq} / \mathrm{kg}$ of $\mathrm{DM}$ ) of the prepartum treatment TMR were more negative than the corresponding formulation values of -152 and $-150 \mathrm{mEq} / \mathrm{kg}$ of $\mathrm{DM}$, respectively. Although measured $\mathrm{P}$ concentrations were within $5 \%$ of formulated values, values for $\mathrm{Na}(-27 \%), \mathrm{Cl}(-18 \%)$, $\mathrm{K}(-20 \%), \mathrm{Mg}(-10 \%)$, and $\mathrm{Ca}(-34 \%)$ were less and $\mathrm{S}(+16 \%)$ concentration was greater relative to their respective formulation values for the lactation TMR. There was a larger discrepancy between the formulated and measured DCAD values (decrease from 296 to 153 $\mathrm{mEq} / \mathrm{kg}$ of $\mathrm{DM}$ ) of the postpartum TMR.

A total of 66 cows were enrolled, and 4 were removed (3 calved early, 1 feeding error) during the treatment phase (dry period) of the study. The remaining 62 cows completed the dry period (Table 3). Distribution of cows in parity 2 and 3 was similar among treatment groups. Calving dates of the smaller number of cows in parity $4+$ resulted in a less-balanced distribution of these cows among treatment groups. Days on treatment was similar among groups. Due to health concerns, 6 cows were removed after calving (Table 3). Thus, 56 cows completed the lactation phase of the study.

\section{Urine $\mathrm{pH}$}

There was no effect of the covariate $(P=0.98)$ on urine $\mathrm{pH}$ during the treatment phase. Urine $\mathrm{pH}$ decreased from 8.15 to $6.12 \pm 0.13$ upon treatment initiation and was not affected by treatment, breed, week, or any of the interactions during the treatment phase $(P$ $>0.36$; Table 4, Figure 1A). Urine $\mathrm{pH}$ increased after calving and was similar to pretreatment values by 3 DIM $(8.23 \pm 0.16)$. During the first 3 DIM, there was a treatment $\times$ breed $\times$ DIM interaction $(P=0.03)$ as the increase in urine $\mathrm{pH}$ in $\mathrm{SC}-\mathrm{HO}$ cows was less from 1 to 2 DIM and greater from 2 to 3 DIM compared with the other groups (Table 5 ). There was also a breed $\times$ week interaction $(P=0.04)$ during lactation as the increase in $\mathrm{HO}$ cows was delayed relative to the increase in $\mathrm{XX}$ cows (Table 6). During lactation, urine $\mathrm{pH}$ was greater in cows that consumed SC $(P<0.01)$.

\section{Serum Component Concentrations}

There were covariate effects $(P<0.01)$ for $\mathrm{Ca}$ and all other measured serum components except BHB $(P$ $=0.30)$ prepartum. Serum Ca concentrations were not altered by any of the main effects $(P>0.11)$ or their interactions $(P>0.35)$ during the prepartum period 


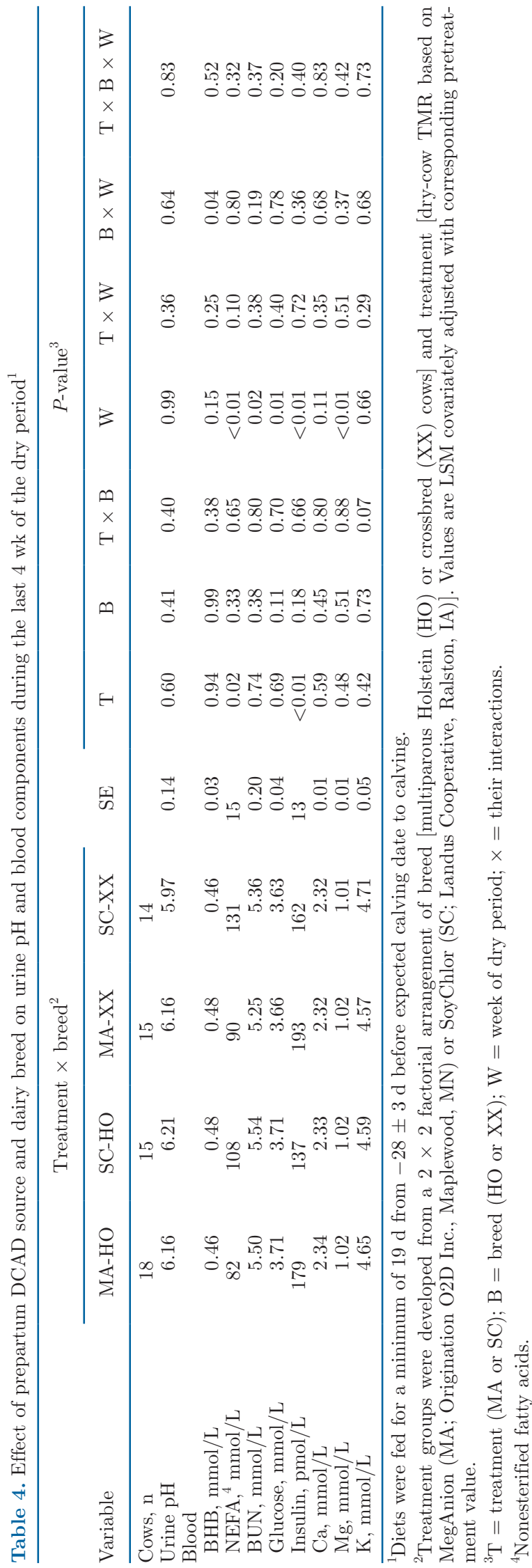

(Table 4; Figure 1B) but decreased immediately after calving and increased from d 1 to $3(P<0.01$; Table $5)$. Only 3 cows ( $1 \mathrm{MA}-\mathrm{HO}$ and $2 \mathrm{MA}-\mathrm{XX})$ had serum Ca concentrations $<2.0 \mathrm{mmol} / \mathrm{L}$ on each of the first 3 DIM, whereas 18 cows (3 MA-HO, 6 MA-XX, 5 SC$\mathrm{HO}$, and 4 SC-XX) had serum Ca concentrations less

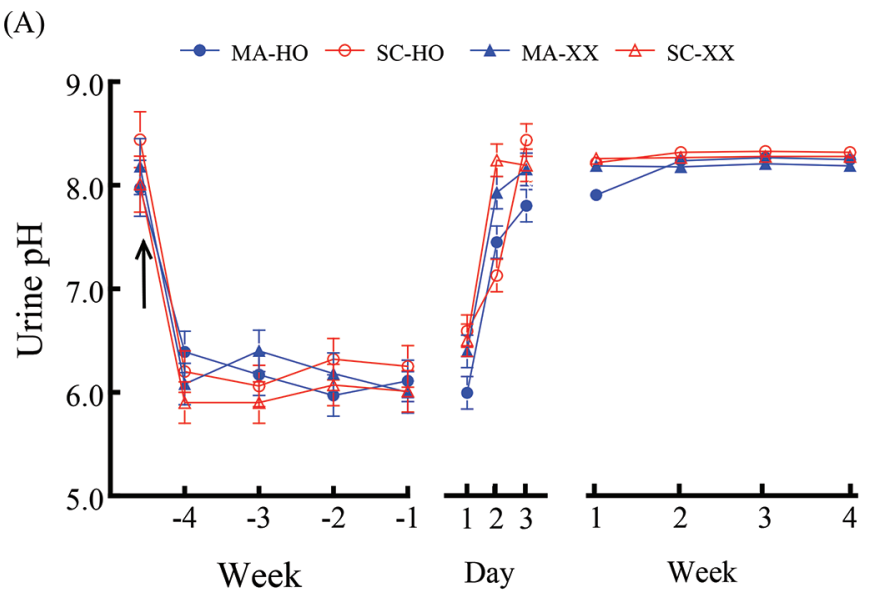

(B)

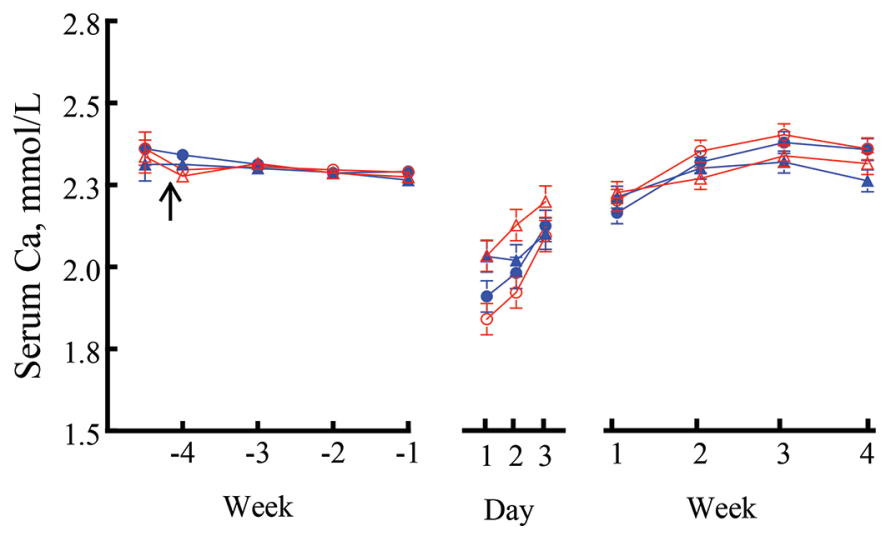

Figure 1. Peripartum urine $\mathrm{pH}(\mathrm{A})$ and serum $\mathrm{Ca}$ concentrations (B) of multiparous Holstein (HO) or crossbred (XX) cows fed MegAnion (MA; Origination O2D Inc., Maplewood, MN) or SoyChlor (SC; Landus Cooperative, Ralston, IA) during the 4 wk before expected calving. Data represent LSM \pm SEM. There were $18,15,15$, and 14 prepartum cows and $15,12,15$, and 14 postpartum cows in the MA-HO, SC-HO, MA-XX, and SC-XX groups, respectively. (A) Urine $\mathrm{pH}$ decreased upon treatment initiation but was not affected by treatment, breed, week or day of lactation, or their interactions $(P>$ $0.36)$ during the treatment phase of the study. There was a treatment $\times$ breed $\times$ DIM interaction $(P=0.03)$ during the first 3 DIM. Urine $\mathrm{pH}$ was affected by prepartum treatment $(P<0.01)$ and a breed $\times$ week interaction $(P=0.04)$ during the first $4 \mathrm{wk}$ of lactation but was not affected by any other interaction $(P>0.44)$. (B) Serum Ca concentration was not affected $(P>0.11)$ by treatment, breed, week, or their interactions during the treatment phase of the study. During the first 3 DIM, serum Ca was not affected by treatment $(P=0.86)$ or any interactions $(P>0.11)$ but was affected by breed $(P=0.03)$ and DIM $(P<0.01)$. During the first 4 wk of lactation, serum Ca was affected by week $(P<0.01)$ but not treatment, breed, or any interactions $(P>$ $0.17)$. Arrow indicates the start of treatment. 
Caixeta et al.: SOURCE OF NEGATIVE DIETARY CATION-ANION DIFFERENCE
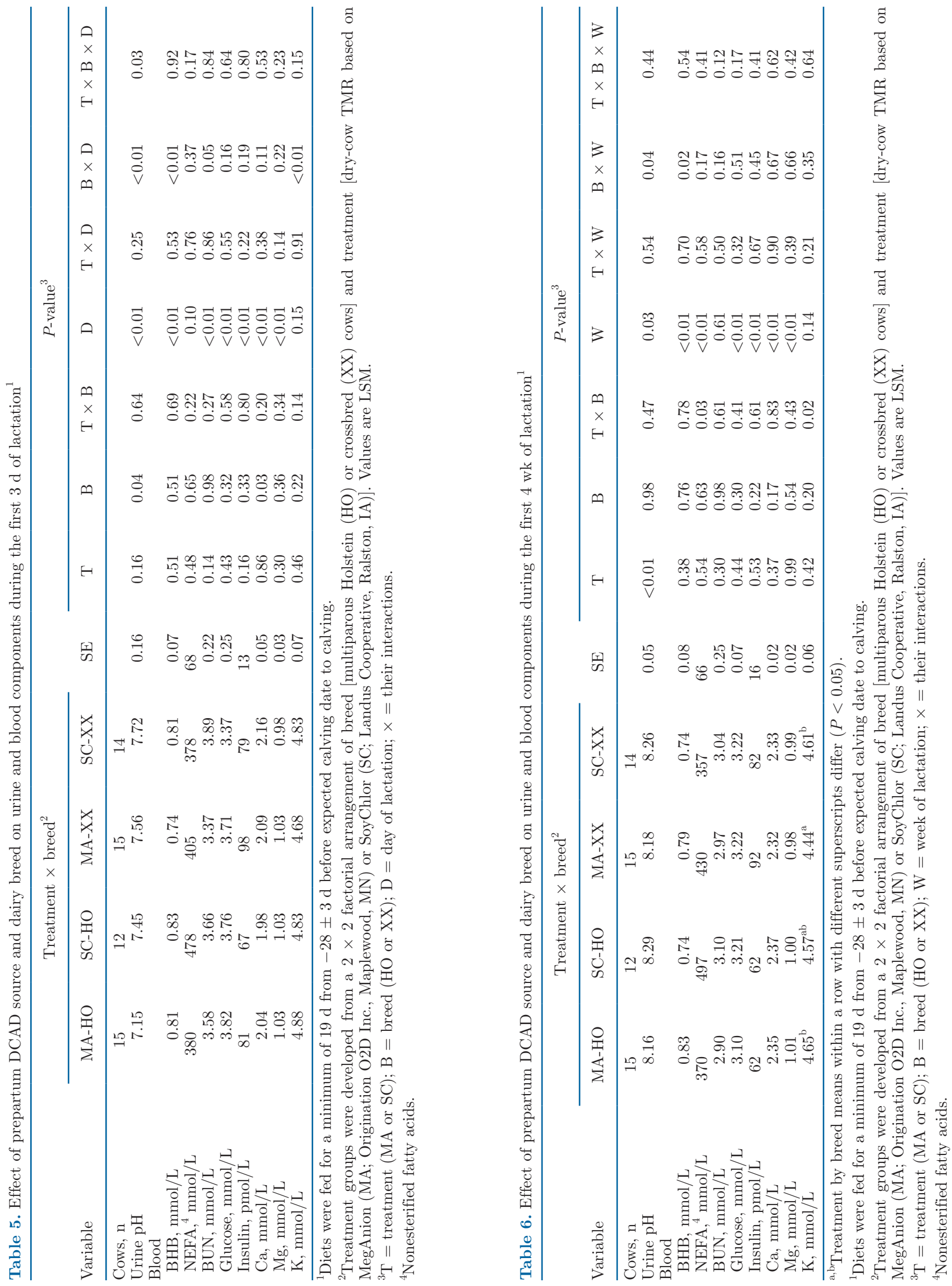
than a higher cutoff $(<2.15 \mathrm{mmol} / \mathrm{L})$ for hypocalcemia on all $3 \mathrm{~d}$ of this interval. Serum Ca concentrations continued to increase $(P<0.01)$ from wk 1 to 2 of lactation (Table 6).

Serum NEFA concentrations were greater $(P=0.02)$ in $\mathrm{SC}$ cows before calving and increased $(P<0.01)$ in all cows as they approached parturition (Table 4$)$. There was a trend $(P=0.10)$ for a treatment $\times$ week interaction as this increase in NEFA concentration was greater in SC cows than in MA cows by wk -1 of lactation. There was a prepartum treatment $\times$ breed interaction $(P=0.03)$ as postpartum NEFA concentrations were greater in MA-XX cows than in SC-XX cows and less in MA-HO cows than in SC-HO cows, which was primarily due to the greater NEFA concentrations in SC-HO cows at wk 1 of lactation (Table 6).

Serum insulin concentrations during the prepartum treatment period (Table 4$)$ were greater $(P<0.01)$ in cows that consumed MA than in those that consumed SC. Serum glucose concentrations were not affected $(P$ $>0.11$ ) by treatment, breed, or any of the main effect interactions at any phase of the study. There was no effect of treatment or interactions of treatment with other main effects on serum BHB $(P>0.25)$ or BUN $(P>0.12)$ concentration in any phase of the study (profiles not presented).

There was a trend $(P=0.07)$ for a treatment $\times$ breed interaction as the prepartum serum potassium concentrations (profiles not presented) were less in $\mathrm{SC}-\mathrm{HO}$ cows than in MA-HO cows but greater in SCXX cows than in MA-XX cows (Table 4). This same interaction $(P=0.03)$ of treatment $\times$ breed on potassium concentrations was also detected during the postpartum period (Table 6). There was no effect of treatment on serum $\mathrm{Mg}$ concentrations $(P>0.23)$ in any phase of the study, but $\mathrm{Mg}$ concentrations (profiles not presented) increased in all cows at calving.

\section{Animal Performance}

There were no effects of treatment $(P>0.17)$ or interactions of treatment with other main effects $(P$ $>0.29$ ) on prepartum DMI (Table 7 ). There was a treatment $\times$ week of lactation interaction on postpartum DMI $(P=0.05)$ as the postpartum increase was greater for SC cows than for MA cows (Table 8; Figure $2 \mathrm{~A})$. There were no effects of treatment $(P>0.19)$ or interactions of treatment with other main effects $(P$ $>0.14$ ) on any of the other prepartum or postpartum production variables. Although their milk contained less $(P<0.01)$ protein, $\mathrm{HO}$ cows produced more $3.5 \%$ FCM $(P<0.04)$ than XX cows (Figure $2 \mathrm{~B})$. The XX cows had greater BCS than the HO cows $(P<0.01)$ throughout the study.

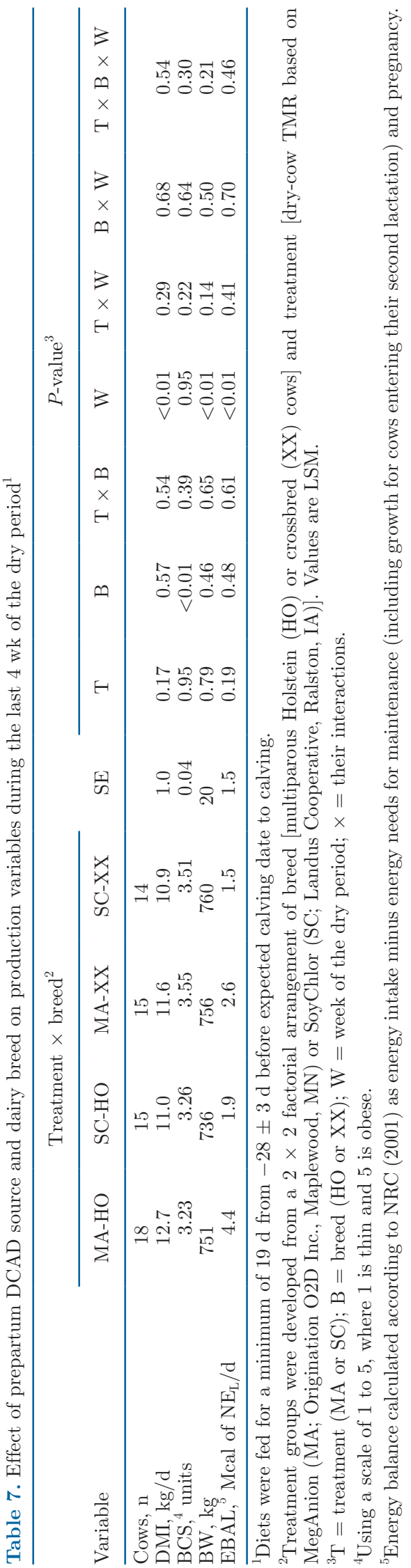




\section{DISCUSSION}

Feeding negative-DCAD diets prepartum has been extensively used in the dairy industry to improve periparturient $\mathrm{Ca}$ homeostasis and decrease the incidence of clinical hypocalcemia and SCH during the early postpartum period. In agreement with our hypothesis that prepartum diets formulated with different sources of anionic salts but with similar DCAD values would provide similar physiological benefits, the urine $\mathrm{pH}$, serum Ca concentrations, and DMI of periparturient

(A)

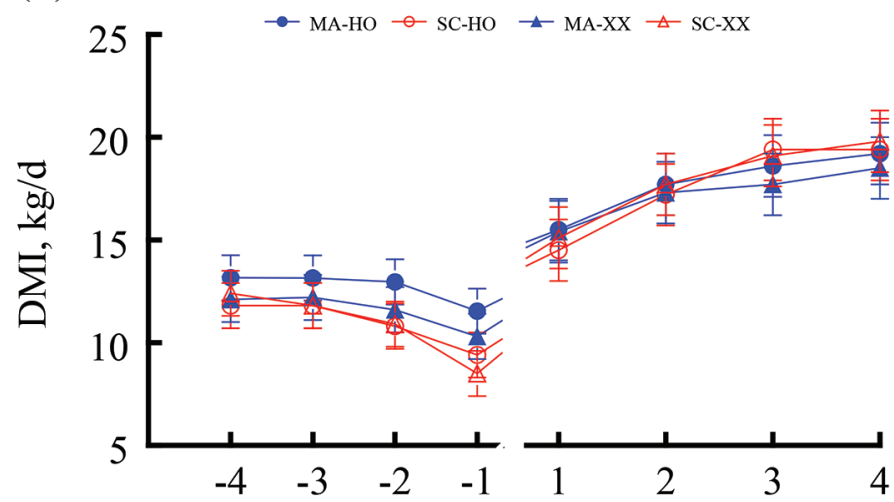

(B)

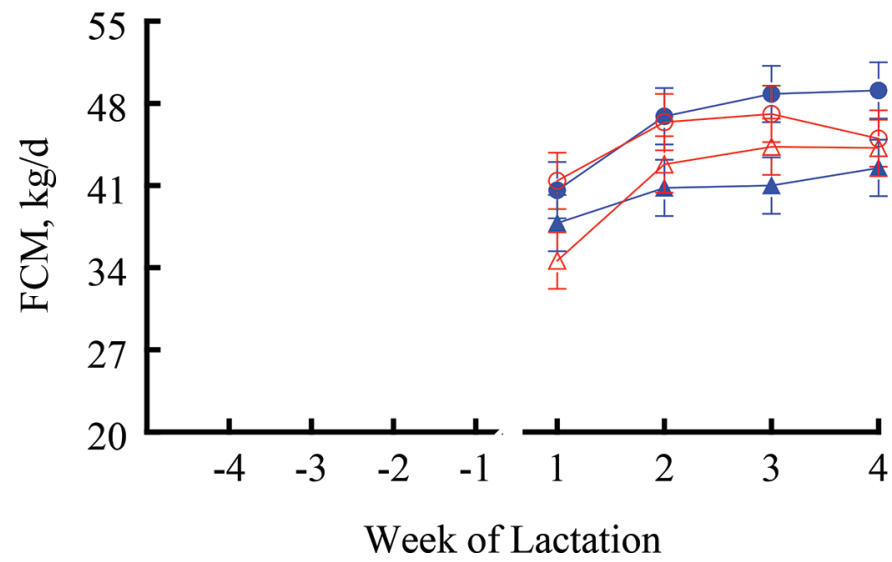

Figure 2. Peripartum DMI (A) and 3.5\% FCM yield (B) of multiparous Holstein (HO) or crossbred (XX) cows fed MegAnion (MA Origination O2D Inc., Maplewood, MN) or SoyChlor (SC; Landus Cooperative, Ralston, IA) during the 4 wk before expected calving. Data represent LSM \pm SEM. There were 18, 15, 15, and 14 prepartum cows and 15, 12, 15, and 14 postpartum cows in the MA-HO, SCHO, MA-XX, and SC-XX groups, respectively. (A) Prepartum DMI decreased $(P<0.01)$ as cows neared calving but was not affected by treatment, breed, or any of the interactions $(P>0.17)$. During the first 4 wk of lactation DMI was affected by week $(P<0.01)$ and a treatment $\times$ week interaction $(P=0.05)$. Breed and all other interactions had no effect on DMI $(P>0.55)$. (B) During the first 4 wk of lactation, yield of $3.5 \%$ FCM was affected by week $(P<0.01)$ and breed $(P<0.04)$ but was not affected by prepartum diet or any of the interactions $(P>0.25)$.

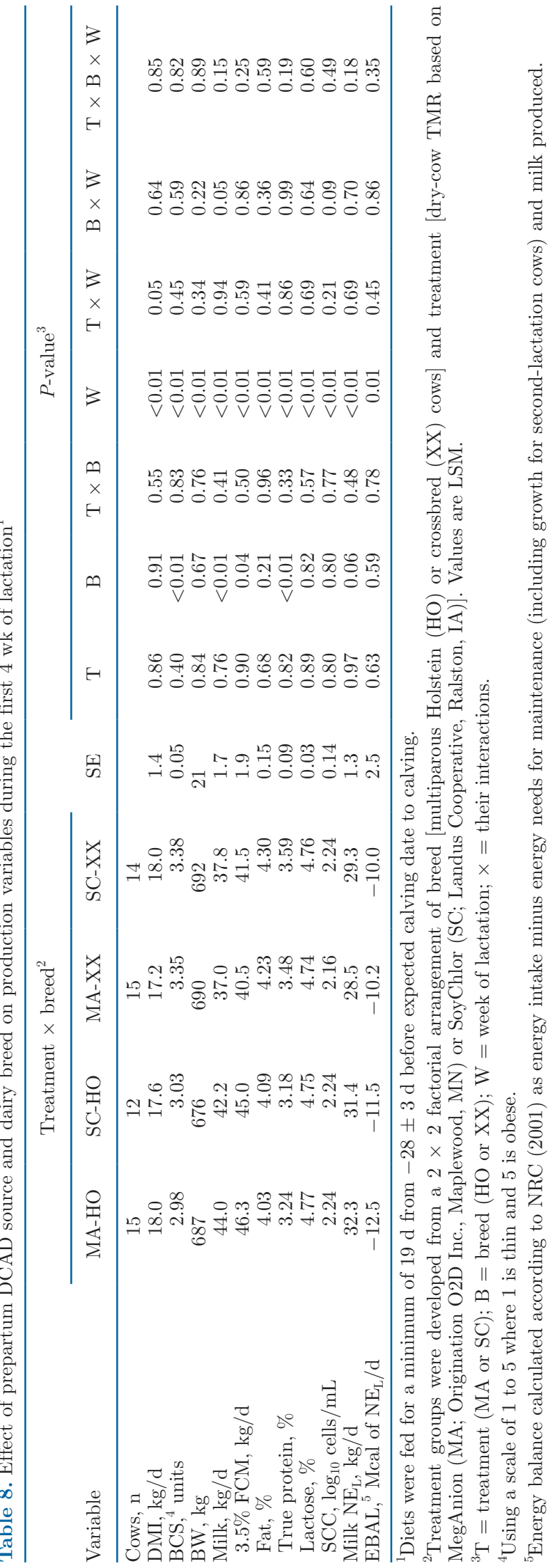


cows were similar between the DCAD treatments in this study. Urine $\mathrm{pH}$ has been used as a practical surrogate to assess whether the source and amount of anionic salts fed to dairy cows during the prepartum period are sufficient to induce the intended metabolic acidosis (Jardon, 1995; Goff, 2008). Although less MA than $\mathrm{SC}$ was needed to obtain similar DCAD values for the TMR, the anionic supplements effectively reduced prepartum urine $\mathrm{pH}$ to a similar extent, which indicates that a comparable state of metabolic acidosis had been induced. These decreases in urine $\mathrm{pH}$ during the treatment period were consistent with values expected when feeding TMR with a DCAD between -100 and $-200 \mathrm{mEq} / \mathrm{kg}$ of DM (Lopera et al., 2018; Zimpel et al., 2018; Santos et al., 2019).

The compensated metabolic acidosis induced by feeding negative-DCAD diets is expected to increase Ca mobilization from bone but typically does not alter serum Ca concentrations during the treatment period (Lean et al., 2019; Santos et al., 2019), and prepartum serum Ca concentrations did not differ between the treatments in this study. The increased Ca mobilization is expected to increase $\mathrm{Ca}$ availability at calving, which should reduce the magnitude of the well-described postpartum decrease in Ca concentration (Caixeta et al., 2015; Leno et al., 2017; Neves et al., 2018), and this should reduce the occurrence of SCH. Serum Ca concentrations decreased immediately after calving in this study, and both of our DCAD treatment groups had cows with postpartum Ca concentrations less than an upper serum Ca concentration cutoff estimate of 2.15 mmol/L (Martinez et al., 2012; Caixeta et al., 2017) and less than the traditional $2.0 \mathrm{mmol} / \mathrm{L}$ cutoff (Reinhardt et al., 2011) for SCH during the first 3 DIM. Two cows on each treatment were removed due to clinical milk fever, but serum $\mathrm{Ca}$ concentrations in all but 1 of the 56 cows that completed the study were $>2.0$ $\mathrm{mmol} / \mathrm{L}$ by wk 1 of lactation. As other DCAD studies have demonstrated, feeding prepartum cows a negativeDCAD diet reduces but does not eliminate incidence of milk fever or SCH (Ramos-Nieves et al., 2009; Santos et al., 2019).

Without a positive-DCAD diet to compare against, it is not possible to assess the effect of treatment on incidence of $\mathrm{SCH}$ in our study, but the results do indicate that cows fed MA had postpartum serum Ca concentration profiles that matched those of cows fed a successful commercial DCAD product. Although statistical power of the study was reduced due to the removal of 6 cows, the actual difference between serum Ca concentrations $(0.02 \mathrm{mmol} / \mathrm{L})$ was considerably less than what the study was designed to detect $(0.08$ $\mathrm{mmol} / \mathrm{L})$. This small difference in serum Ca concentration has little, if any, biological relevance and supports our hypothesis that when used to develop TMR with comparable DCAD values, the products provide similar benefits to the cow. The treatment differences for DMI were also less than what the study was designed to detect. Thus, the reduction in number of observations per treatment did not have a detrimental effect on our ability to compare these commercial products.

Feeding anionic salts can improve periparturient $\mathrm{Ca}$ homeostasis and postpartum DMI, but negative-DCAD diets also typically reduce prepartum DMI (Charbonneau et al., 2006; Lopera et al., 2018; Martinez et al., 2018). The chloride-based anionic supplements used in this study are complexed with soybean meal and are marketed as being palatable and able to minimize the effect of DCAD diets on prepartum DMI. Perhaps the greater $\mathrm{Cl}$ content and the associated reduction in the amount of MA needed to achieve the target DCAD value contributed to the numerically greater DMI by cows fed MA just before calving. Our study did not have a positive-DCAD diet for comparison, but other than the numerically lower DMI just before calving by cows fed SC, prepartum DMI did not differ between the treatments. Interestingly, there was an interaction of treatment and week on postpartum DMI, primarily due to the greater increase in DMI from wk 1 to wk 4 of lactation by cows previously fed SC. The data generated in this study are insufficient to determine whether this is due to feeding SC to prepartum cows, whether it is a consequence of the at least numerically greater reduction in DMI just before calving by cows fed SC, or whether it is due to some other unrecognized component(s).

Poor palatability of salts (Oetzel et al., 1988) and negative effects of the induced metabolic acidosis (Vagnoni and Oetzel, 1998) have been proposed as potential explanations for the reduced prepartum DMI of cows fed negative-DCAD diets. Refinements in formulation of DCAD diets have included efforts to reduce the potential negative effect of anionic salt source on prepartum DMI, and recent studies have reported no reduction in prepartum DMI (DeGroot et al., 2010). However, meta-analyses indicate that although anionic salt source can affect magnitude of the prepartum decrease in DMI, this reduction in DMI appears to occur regardless of the source (Charbonneau et al., 2006; Santos et al., 2019). MegAnion is a relatively new product and thus was not included in this meta-analysis (Santos et al., 2019).

In an elegant experiment, Zimpel et al. (2018) demonstrated that the prepartum reduction in DMI is primarily mediated by the metabolic acidosis created by the consumption of anionic salts and not by the addition of the acidogenic salts to the diet per se. We did not measure blood $\mathrm{pH}$ during the prepartum period 
when cows consumed the DCAD diets. However, the similar prepartum urine $\mathrm{pH}$ values in our study support the likelihood that the lack of a statistical difference in DMI between our DCAD treatment groups was due in part to a similar degree of metabolic acidosis.

The value of feeding prepartum TMR with negative DCAD on subsequent postpartum performance has been well established. A recent meta-analysis indicated that source of anionic salt had no effect on milk yield or composition, BCS, BW, or energy balance (Santos et al., 2019), but few studies have evaluated the source of the anionic salt used to formulate the negative-DCAD TMR. Although DMI did not differ, daily 3.5\% FCM yield by multiparous cows was greater when the cows were fed commercial DCAD products rather than feedgrade anionic salts (DeGroot et al., 2010). Neither DMI nor milk yield were affected by commercial DCAD source when DCAD values were slightly positive (Rezac et al., 2014). Our prepartum TMR were formulated to have similar DCAD values, used commercial sources designed to minimize adverse effects on DMI, and, as expected, had similar effects on postpartum performance. Other than the expected differences due to week or day of lactation, breed was the only main effect that affected production measurements in this study. Breed differences, especially in serum components during the first 3 DIM, in general reflected the more rapid onset of copious milk production by the HO cows.

The DCAD values of our prepartum treatment TMR were more negative than our formulation $(-215$ vs. $-150 \mathrm{mEq} / \mathrm{kg}$ of $\mathrm{DM}$ ), and a larger discrepancy occurred between the measured and formulated DCAD values (153 vs. $296 \mathrm{mEq} / \mathrm{kg}$ of $\mathrm{DM}$ ) for the lactation TMR. Variation between formulated and measured minerals and resulting DCAD values are not uncommon (Santos et al., 2019) and have included discrepancies as large as those reported here (Rezac et al., 2014). These discrepancies are most likely due to variation in mineral content of forages and other dietary ingredients (St-Pierre and Weiss, 2017; Santos et al., 2019), mixing errors, and sampling errors. For all 3 TMR used in this study, the formulated and measured macronutrient contents were similar, which indicates that a major mixing error was unlikely the cause of the discrepancies in mineral content.

We sampled and analyzed the TMR rather than individual ingredients, and although the TMR had typical moisture content, it is possible that these reduced mineral values were the result of nonrepresentative sampling due to incomplete capture of minerals that settled out from the TMR. However, the effect on individual elements was not uniform. For example, although the analytical values for $\mathrm{K}$ decreased, the values for $\mathrm{S}$ increased. The decreased $\mathrm{K}$ and increased
$\mathrm{S}$ analytical values along with only small discrepancies between formulated and analytical values for $\mathrm{Na}$ and $\mathrm{Cl}$ contributed to a more negative DCAD than what was formulated for the 2 experimental diets. These differences were similar for each treatment and thus did not compromise our objective of comparing source of anionic salts on cow performance.

Although reduced $\mathrm{Ca}$ intake has been suggested as an approach to reduce hypocalcemia, it is difficult to develop Ca-deficient diets using feeds typically fed to dairy cows (Goff and Koszewski, 2018). The prepartum requirement of our $750-\mathrm{kg}$ cows was about $20 \mathrm{~g}$ of absorbable $\mathrm{Ca} / \mathrm{d}$ (NRC, 2001), which they easily achieved (NRC, 2001) whether dietary Ca was $0.8 \%$ (our formulation value) or $0.5 \%$ (our analytical value). Goff and Koszewski (2018) demonstrated that serum Ca concentrations did not differ in prepartum cows fed negative-DCAD diets that contained 0.46 or $0.72 \% \mathrm{Ca}$. Thus, the reduced dietary Ca concentration indicated by analysis of our TMR should have no effect on our objective of comparing source of anionic salts on cow performance. Reduced analytical values for $\mathrm{Na}, \mathrm{K}$, and $\mathrm{Cl}$ and a larger increase in measured $\mathrm{S}$ concentration were responsible for the greater difference between formulated and analytical DCAD values for the lactation TMR. The largest effect of the decreased DCAD content of the lactation TMR might have been a reduction in DMI $(<0.5 \mathrm{~kg} / \mathrm{d})$ and $3.5 \% \mathrm{FCM}$ yield $(<1.0$ $\mathrm{kg} / \mathrm{d}$; Iwaniuk and Erdman, 2015). However, all cows consumed the same lactation TMR, so any effect of this low-DCAD postpartum TMR on the ability to compare the salt sources should be similar.

A recent meta-analysis (Santos et al., 2019) indicated that prepartum DCAD probably does not need to be less than $-150 \mathrm{mEq} / \mathrm{kg}$ of DM, but only a few studies with DCAD values between -150 and $-200 \mathrm{mEq} / \mathrm{kg}$ of DM were available for the meta-analysis, and this contributed to the inability to detect an optimum DCAD value. Not included in this meta-analysis (Santos et al., 2019) was a study that fed prepartum TMR with DCAD values of -21 and $-211 \mathrm{mEq} / \mathrm{kg}$ of DM to multiparous $\mathrm{HO}$ beginning $28 \mathrm{~d}$ prepartum and evaluated performance through 63 DIM (Diehl et al., 2018). The TMR with more negative DCAD decreased urine $\mathrm{pH}$ and prepartum DMI, increased fractional excretion of $\mathrm{Ca}$, did not alter postpartum DMI, and increased milk yield from 45 to 63 DIM relative to the TMR with less negative DCAD (Diehl et al., 2018). Our treatment DCAD values $(-150 \mathrm{mEq} / \mathrm{kg}$ of $\mathrm{DM}$ from the formulation or $-215 \mathrm{mEq} / \mathrm{kg}$ of DM from the analysis) are more negative than those used in several previous studies but are within the range that has demonstrated beneficial effects on postpartum DMI and performance. Additional improvements in postpartum performance 
could be achieved by more research to determine the optimum prepartum DCAD value needed to support periparturient $\mathrm{Ca}$ homeostasis and to better understand the factors that affect the dynamics of DMI in the periparturient cow.

\section{CONCLUSIONS}

The DCAD values of the prepartum treatment TMR reduced prepartum urine $\mathrm{pH}$ and presumably created a similar state of metabolic acidosis in cows fed MA or SC. Serum Ca concentrations were not affected by source of anionic salt, and, after the expected decrease at calving, Ca concentrations increased rapidly in cows that consumed either anionic supplement. The source of anionic supplement did not affect pre- or postpartum DMI or any other production variables or postpartum serum components. Prepartum serum concentrations of NEFA were reduced and concentrations of insulin were greater in cows fed MA than in cows fed SC. These differences were supported by the numerical increases in prepartum DMI and energy balance of cows fed MA. Compared with SC, the results indicate that MA provides another effective source of anionic salts for diets designed to induce metabolic acidosis in prepartum dairy cows.

\section{ACKNOWLEDGMENTS}

This work was supported in part by the University of Minnesota Agricultural Experiment Station (St. Paul). The authors also acknowledge and thank Origination O2D Inc. (Maplewood, MN) for partial financial support of this project. J. Faser was employed by Origination O2D Inc. and B. Visser was employed by Vita Plus Corporation (Madison, WI) when this study was conducted. These coauthors helped develop the study and reviewed the manuscript but were not involved with any of the data analyses. Fei Sun from Origination O2D Inc. also provided review comments. All other authors have no conflicts to declare. The authors appreciate the excellent animal care and courteous assistance provided throughout the study by Saige Sulzberger and the staff at the University of Minnesota, St. Paul campus dairy. We also acknowledge and appreciate the valuable health care provided by Bobwealth Omontese (University of Minnesota, College of Veterinary Medicine, St. Paul) and his assistance with sample collection.

\section{REFERENCES}

Ankom Technology. 2017. Acid detergent fiber and neutral detergent fiber methods. Accessed Nov. 20, 2019. https://www.ankom.com/ analytical-methods-support/fiber-analyzer-a200.
AOAC International. 2006. Official Methods of Analysis. 20th ed. Assoc. Off. Anal. Chem., Arlington. VA.

Caixeta, L. S., P. A. Ospina, M. B. Capel, and D. V. Nydam. 2015. The association of subclinical hypocalcemia, negative energy balance and disease with bodyweight change during the first 30 days post-partum in dairy cows milked with automatic milking systems. Vet. J. 204:150-156. https://doi.org/10.1016/j.tvjl.2015.01.021.

Caixeta, L. S., P. A. Ospina, M. B. Capel, and D. V. Nydam. 2017. Association between subclinical hypocalcemia in the first 3 days of lactation and reproductive performance of dairy cows. Theriogenology 94:1-7. https://doi.org/10.1016/j.theriogenology.2017.01 .039 .

Cantliffe, D. J., G. E. MacDonald, and N. H. Peck. 1970. The potentiometric determinations of nitrate and chloride in plant tissue. New York Food Life Sci. Bull. 3:7.

CEM Corporation. 2019. MARS 6 microwave acid digestion. Accessed Nov. 20, 2019. http://cem.com/mars-6-method-note-compendium.

Chapinal, N., M. Carson, T. F. Duffield, M. Capel, S. Godden, M. Overton, J. E. Santos, and S. J. LeBlanc. 2011. The association of serum metabolites with clinical disease during the transition period. J. Dairy Sci. 94:4897-4903. https://doi.org/10.3168/jds .2010-4075.

Charbonneau, E., D. Pellerin, and G. R. Oetzel. 2006. Impact of lowering dietary cation-anion difference in nonlactating dairy cows: A meta-analysis. J. Dairy Sci. 89:537-548. https://doi.org/10.3168/ jds.s0022-0302(06)72116-6.

DeGroot, M. A., E. Block, and P. D. French. 2010. Effect of prepartum anionic supplementation on periparturient feed intake, health, and milk production. J. Dairy Sci. 93:5268-5279. https://doi.org/10 $.3168 /$ jds.2010-3092.

Diehl, A. L., J. K. Bernard, S. Tao, T. N. Smith, D. J. Kirk, D. J. McLean, and J. D. Chapman. 2018. Effect of varying prepartum dietary cation-anion difference and calcium concentration on postpartum mineral and metabolite status and milk production of multiparous cows. J. Dairy Sci. 101:9915-9925. https://doi.org/10 $.3168 /$ jds.2018-14828.

Goff, J. P. 2008. The monitoring, prevention, and treatment of milk fever and subclinical hypocalcemia in dairy cows. Vet. J. 176:50-57. https://doi.org/10.1016/j.tvjl.2007.12.020.

Goff, J. P. 2018. Invited review: Mineral absorption mechanisms, mineral interactions that affect acid-base and antioxidant status, and diet considerations to improve mineral status. J. Dairy Sci 101:2763-2813. https://doi.org/10.3168/jds.2017-13112.

Goff, J. P., and R. L. Horst. 2003. Role of acid-base physiology on the pathogenesis of parturient hypocalcaemia (milk fever)-The DCAD theory in principal and practice. Acta Vet. Scand. Suppl. 97:51-56.

Goff, J. P., and N. J. Koszewski. 2018. Comparison of $0.46 \%$ calcium diets with and without added anions with a $0.7 \%$ calcium anionic diet as a means to reduce periparturient hypocalcemia. J. Dairy Sci. 101:5033-5045. https://doi.org/10.3168/jds.2017-13832.

Iwaniuk, M. E., and R. A. Erdman. 2015. Intake, milk production, ruminal, and feed efficiency responses to dietary cation-anion difference by lactating dairy cows. J. Dairy Sci. 98:8973-8985. https: //doi.org/10.3168/jds.2015-9949.

Jardon, P. W. 1995. Using urine $\mathrm{pH}$ to monitor anionic salt programs. Compend. Contin. Educ. Pract. Vet. 17:860-862.

Lean, I. J., J. E. P. Santos, E. Block, and H. M. Golder. 2019. Effects of prepartum dietary cation-anion difference intake on production and health of dairy cows: A meta-analysis. J. Dairy Sci. 102:21032133. https://doi.org/10.3168/jds.2018-14769.

Leno, B. M., C. M. Ryan, T. Stokol, D. Kirk, K. P. Zanzalari, J. D. Chapman, and T. R. Overton. 2017. Effects of prepartum dietary cation-anion difference on aspects of peripartum mineral and energy metabolism and performance of multiparous Holstein cows. J. Dairy Sci. 100:4604-4622. https://doi.org/10.3168/jds.2016-12221.

Lopera, C., R. Zimpel, A. Vieira-Neto, F. R. Lopes, W. Ortiz, M. Poindexter, B. N. Faria, M. L. Gambarini, E. Block, C. D. Nelson, and J. E. P. Santos. 2018. Effects of level of dietary cation-anion difference and duration of prepartum feeding on performance and 
metabolism of dairy cows. J. Dairy Sci. 101:7907-7929. https://doi .org/10.3168/jds.2018-14580.

Martín-Tereso, J., and M. W. Verstegen. 2011. A novel model to explain dietary factors affecting hypocalcaemia in dairy cattle. Nutr. Res. Rev. 24:228-243. https://doi.org/10.1017/S0954422411000126.

Martinez, N., C. A. Risco, F. S. Lima, R. S. Bisinotto, L. F. Greco, E. S. Ribeiro, F. P. Maunsell, K. N. Galvão, and J. E. P. Santos, 2012. Evaluation of peripartal calcium status, energetic profile, and neutrophil function in dairy cows at low or high risk of developing uterine disease. J. Dairy Sci. 95:7158-7172. https://doi.org/ 10.3168/jds.2012-5812.

Martinez, N., R. M. Rodney, E. Block, L. L. Hernandez, C. D. Nelson, I. J. Lean, and J. E. P. Santos. 2018. Effects of prepartum dietary cation-anion difference and source of vitamin D on dairy cows: Lactation performance and energy metabolism. J. Dairy Sci. 101:2544-2562. https://doi.org/10.3168/jds.2017-13739.

Murray, R. D., J. E. Horsfield, W. D. McCormick, H. J. Williams, and D. Ward. 2008. Historical and current perspectives on the treatment, control and pathogenesis of milk fever in dairy cattle. Vet. Rec. 163:561-565. https://doi.org/10.1136/vr.163.19.561.

Neves, R. C., B. M. Leno, K. D. Bach, and J. A. A. McArt. 2018. Epidemiology of subclinical hypocalcemia in early-lactation Holstein dairy cows: The temporal associations of plasma calcium concentration in the first 4 days in milk with disease and milk production. J. Dairy Sci. 101:9321-9331. https://doi.org/10.3168/ jds.2018-14587.

NRC. 2001. Nutrient Requirements of Dairy Cattle. 7th rev. ed. Natl. Acad. Press, Washington, DC.

Oetzel, G. R., and B. E. Miller. 2012. Effect of oral calcium bolus supplementation on early lactation health and milk yield in commercial dairy herds. J. Dairy Sci. 95:7051-7065. https://doi.org/ $10.3168 /$ jds.2012-5510

Oetzel, G. R., J. D. Olson, C. R. Curtis, and M. J. Fettman. 1988. Ammonium chloride and ammonium sulfate for prevention of parturient paresis in dairy cows. J. Dairy Sci. 71:3302-3309. https:// doi.org/10.3168/jds.S0022-0302(88)79935-X.

Origination O2D Inc. 2019. MegAnion specifications. Accessed Nov. 20, 2019. https://originationo2d.com/feed-ingredients/dcad -formulating/.

Ramos-Nieves, J. M., B. J. Thering, M. R. Waldron, P. W. Jardon, and T. R. Overton. 2009. Effects of anion supplementation to lowpotassium prepartum diets on macromineral status and performance of periparturient dairy cows. J. Dairy Sci. 92:5677-5691. https://doi.org/10.3168/jds.2009-2378.
Reinhardt, T. A., J. D. Lippolis, B. J. McCluskey, J. P. Goff, and R. L. Horst. 2011. Prevalence of subclinical hypocalcemia in dairy herds. Vet. J. 188:122-124. https://doi.org/10.1016/j.tvjl.2010.03.025.

Rezac, D. J., E. Block, D. Weber, M. Brouk, and B. Bradford. 2014 Effects of prepartum dietary cation-anion difference and acidified coproducts on dry matter intake, serum calcium, and performance of dairy cows. J. Anim. Sci. 92:666-675. https://doi.org/10.2527/ jas.2013-6317.

Santos, J. E. P., I. J. Lean, H. Golder, and E. Block. 2019. Meta-analysis of the effects of prepartum dietary cation-anion difference on performance and health of dairy cows. J. Dairy Sci. 102:2134-2154. https://doi.org/10.3168/jds.2018-14628.

St-Pierre, N., and W. P. Weiss. 2017. Variability in feed sampling and analyses. Pages 713-722 in Large Dairy Herd Management. 3rd ed. D. K. Beede, ed. American Dairy Science Association, Champaign, IL.

Tyrrell, H. F., and J. T. Reid. 1965. Prediction of the energy value of cow's milk. J. Dairy Sci. 48:1215-1223. https://doi.org/10.3168/ jds.S0022-0302(65)88430-2.

Vagnoni, D. B. and G. R. Oetzel. 1998. Effects of dietary-cation anion difference on the acid-base status of dry cows. J. Dairy Sci. 81:1643-1652. https://doi.org/10.3168/jds.S0022-0302(98)75732 $-7$.

Van Soest, P. J., J. B. Robertson, and B. A. Lewis. 1991. Methods for dietary fiber, neutral detergent fiber, and nonstarch polysaccharides in relation to animal nutrition. J. Dairy Sci. 74:3583-3597. https://doi.org/10.3168/jds.S0022-0302(91)78551-2.

Weich, W., E. Block, and N. B. Litherland. 2013. Extended negative dietary cation-anion difference feeding does not negatively affect postpartum performance of multiparous dairy cows. J. Dairy Sci. 96:5780-5792. https://doi.org/10.3168/jds.2012-6479.

Zimpel, R., M. B. Poindexter, A. Vieira-Neto, E. Block, C. D. Nelson, C. R. Staples, W. W. Thatcher, and J. E. P. Santos. 2018. Effect of dietary cation-anion difference on acid-base status and dry matter intake in dry pregnant cows. J. Dairy Sci. 101:8461-8475. https:/ doi.org/10.3168/jds.2018-14748.

\section{ORCIDS}

Luciano S. Caixeta ๑ https://orcid.org/0000-0001-9577-4989

Wanda J. Weber (으 https://orcid.org/0000-0001-6756-8424

Brian A. Crooker @ https://orcid.org/0000-0002-8433-9946 